\title{
Mitologías soberanas: tierras indígenas y construcción de la propiedad privada en Mendoza a fines del siglo XIX
}

\section{( Diego Escolar"}

Fecha de recepción: 11 de marzo de 2020. Fecha de aceptación: 1 de junio de 2020

Palabras clave

propiedad, soberanía y aboriginalidad

ficciones legales territorios indígenas en Argentina huarpes

Key words

property, sovereignty and aboriginality legal fictions

Indigenous territories in Argentina Huarpes

\section{Resumen}

Hasta hace poco, el único caso conocido de una merced real esgrimida por una comunidad indígena para defender sus derechos de tierras era el de Amaicha, en Tucumán. En este artículo abordaré los conflictos en torno a la merced real del cacique Sayanca de las Lagunas de Guanacache, en el norte de Mendoza. Analizaré un momento clave: el escándalo político producido entre fines del siglo XIX y principios del XX por la reivindicación de la merced sobre un cuarto del territorio de la provincia por el abogado francés, Jules Watteau. El caso muestra que en la Argentina "criolla", poblaciones indígenas supuestamente extinguidas pudieron persistir en la ocupación de parte de sus territorios ancestrales adaptándose al proceso colonial en fechas más tardías que las tradicionalmente aceptadas. Además sugiere que el proceso de constitución de la propiedad privada en la provincia produjo antecedentes de reconocimiento de la propiedad indígena en tiempos republicanos, lo cual vició de legitimidad y legalidad su reapropiación posterior.

Sovereign mythologies: indigenous lands and the construction of private property in Mendoza, late 19 th century

\section{Abstract}

Until recently, the only known case in Argentina of a merced real used by an indigenous community to claim their territory was that of Amaicha in Tucumán. In this article I will discuss the conflicts over cacique Sayanca of Guanacache's merced real, north of Mendoza province. A key moment analyzed is the political scandal produced by French lawyer Jules Watteau, and his claim

\footnotetext{
* Consejo Nacional de Investigaciones Científicas y Técnicas (CONICET) - Instituto Argentino de Nivología, Glaciología y Ciencias Ambientales (IANIGLA)/ Universidad Nacional de Cuyo. Mendoza, Argentina. E-mail: descolar@gmail.com
} 
over the merced real -a quarter of the territory of Mendoza between the late 19th and early $20^{\text {th }}$ centuries. The case study shows how indigenous populations persisted in their ancestral territories in "white" Argentina, adapting to the colonial process even later than traditionally accepted. Moreover it suggests that the process of private property left behind an unresolved legacy, regarding the recognition of former indigenous property in Republican times.

\footnotetext{
No debo preocuparme de demostrar que la Merced Real no es un mito [...] la transmisión de la propiedad raíz de más de un siglo en media provincia de Mendoza tiene por base esa misma Merced mitológica.

(Ponce, C. y J. Watteau (1898). "Contra El Debate: Acusación criminal" en Los Andes. 8 de octubre de 1898).
}

Desde los inicios de la conquista española las lagunas de Guanacache, en el norte de la provincia de Mendoza y el borde sur de San Juan fueron consignadas como las principales áreas pobladas por los huarpes y más tarde como zona de refugio de sus remanentes. Y este árido páramo es el principal objeto territorial de uno de los más notables procesos de etnogénesis y emergencia o re-emergencia de identidades indígenas de la Argentina. Aquí es donde se han producido las demandas más insistentes sobre la propiedad de la tierra o incluso un territorio étnico concreto. Sin embargo, el arraigo histórico de tales pretensiones fue desestimado por la tradicional negación de la presencia indígena desde el siglo XVII, por parte de los historiadores y en base a la suposición de que no existían antecedentes documentales, o más específicamente legales, que respaldaran las mismas (Canals Frau, 1946; Michieli, 1983, 2000; Prieto, 1976, 2000, entre otros). No obstante, a lo largo de mis investigaciones pude ir estableciendo que el énfasis local en la propiedad indígena de Guanacache y su entorno -un área no menor a un millón de hectáreas- tenía un claro correlato histórico. Estos reclamos, en efecto, fueron sostenidos a lo largo del siglo XIX y parte del XX y se sustentan en memorias, relatos orales y archivos que indican una antigua lucha judicial, militar y cultural de los huarpes y sus descendientes por mantener ese territorio a lo largo de la colonización española y republicana. Los laguneros mantuvieron con inusual fuerza este territorio, no sólo a través del sistema legal sino también mediante formas de resistencia pasiva y activa que incluyeron desde movilización electoral, cobro forzado de peajes, robos y saqueos, hasta insurrecciones, guerrilla, guerra civil y golpes de estado. También, sobre todo, implicaron la negociación y articulación con intereses políticos y económicos diversos, a la vez que fueron atravesados por intereses particulares y divisiones internas.

Esta larga historia tuvo como uno de sus ejes la movilización judicial reiterada de archivos y documentos relativos a la propiedad de las tierras de Guanacache por parte de los laguneros, o sus apoderados. Estos documentos fueron preservados en archivos familiares hasta la actualidad y proporcionaron las principales pistas para reconstruir la trayectoria de los conflictos por la tierra y la autonomía en tanto indios, por parte de los laguneros durante los siglos XIX y XX. En otras oportunidades analicé cómo los laguneros utilizaron esos documentos en juicios, al menos desde la década de 1830 (Escolar, 2007, 2013, 2015), creando a su vez expedientes que una vez copiados y atesorados pasaban a engrosar sus archivos para ser utilizados en litigios posteriores. Dos de los documentos principales eran una defensa realizada por el protector de los indios laguneros de Mendoza en la década de 1830, junto con un 
decreto de 1838 que les adjudicó sus tierras en común, y la merced real de 1713 al cacique Diego Sayanca, junto con el testamento del cacique Jacinto Sayanca legando dicha merced a los indios laguneros. La merced real de Sayanca no sólo fue utilizada, en ocasiones, por los laguneros para legitimar o legalizar sus derechos sino que tuvo un recorrido muy controversial en las disputas por las tierras en el norte y este de la provincia desde el siglo XIX hasta la actualidad. Fue una pieza clave, no obstante su discutida autenticidad (Escolar, 2019), en la conformación de la propiedad privada en esa área, un tercio aproximadamente del territorio mendocino. En este trabajo analizaré la relación entre los contradictorios usos de los laguneros y de terceros privados de la merced real para acaparar, en general de forma fraudulenta, las tierras del norte y este de Mendoza hacia fines del siglo XIX. Este período fue crucial en la apropiación de la tierra y el agua por parte de la élite económica y política provincial en el marco del fuerte incentivo generado por el despegue de la vitivinicultura entre las décadas de 1870 y 1900, que reemplazó en forma rápida y creciente el anterior modelo basado en la cría y comercialización de ganado en pie para el mercado chileno (Richard Jorba, 1998). La instauración de este modelo coincidió, no casualmente, con la derrota de los levantamientos montoneros federales de las décadas de 1860 y 1870 y la conquista militar de los territorios indígenas del sur de Mendoza entre 1878 y 1881, durante las "Campañas del Desierto" (Escolar, 2007). Fue impulsado por una pujante burguesía liberal con fuertes rasgos oligárquicos y aliada con las elites porteñas. Desde 1862 comenzó a adquirir el control político y, sin perjuicio de feroces enfrentamientos facciosos e incorporando inclusive antiguos terratenientes y comerciantes de ganado federales, dominó la política local hasta la década de 1910 y -en gran medida- con posterioridad (Bragoni y Richard Jorba, 1993-1998; Bragoni, 1999).

La historiografía regional ha profundizado en el estudio de este proceso atendiendo preponderantemente a la experiencia política y económica de las elites. Mucho menor ha sido el desarrollo investigativo sobre las prácticas, perspectivas y culturas políticas de los grupos subalternos relativas al acceso y propiedad de la tierra, en general, y particularmente en las áreas rurales de zonas semidesérticas denominadas técnicamente "secano", en teoría sin estructura de regadío como las lagunas de Guanacache. Menos aún se ha indagado sobre la existencia y significación de adscripciones étnicas y tradiciones indígenas en dichas áreas. Incluso entre los análisis más destacados la presencia indígena y campesina es simplificada como peones al servicio de los patrones o eventualmente pequeños propietarios y criadores de ganado, sin explicitar el origen y naturaleza de dichas propiedades ni su historia de ocupación o conflictos (Richard Jorba, 2000-2001). Políticamente fueron considerados como meros clientes de la elite, sin tradiciones ni proyectos políticos propios. Por ejemplo, uno de los más valiosos estudios históricos sobre la sociedad, economía y política de la segunda mitad del siglo XIX plantea la inexistencia de una articulación política o "solidaridad horizontal" de los sectores subalternos, aunque reconoce que el tema merece ser explorado en profundidad (Bragoni, 1999: 228-229). En las mismas páginas se califica como un inorgánico bandolero social al célebre montonero Santos Guayama, un caudillo popular lagunero que entre las décadas de 1860 y 1870 disputó el control estatal de gran parte del campo cuyano, especialmente el área de Guanacache, mediando en la política nacional y regional con la solidaridad de los grupos subalternos rurales (Escolar, 2018).

Por tales motivos este artículo busca aportar al conocimiento de la historia de los laguneros de Guanacache reponiendo la complejidad de sus disputas 
seculares por la tierra del área, en tanto indígenas pero también en relación con la historia de la propiedad en Mendoza conectando su experiencia con la de las élites provinciales hacia fines del siglo XIX y principios del siglo XX.

Previamente, es necesario reponer algunas características de las formas de propiedad de la tierra en Mendoza entre la colonia y la república, proceso complejo cuyo conocimiento es crucial pero que aún no ha sido tratado por una investigación de conjunto. Durante el período colonial la tierra era otorgada por la corona o sus representantes políticos a los conquistadores, o sus descendientes como compensación por acuerdos capitulares o servicios prestados a la corona, fundamentalmente militares, a través de mercedes reales. También la corona reconocía, en muchos casos, la propiedad común de las tierras asignadas a grupos indígenas bajo la forma de reducciones o pueblos de indios, tanto para su subsistencia como, hacia mediados del período colonial, para recaudar tributo por las mismas. Hacia fines del siglo XVI se estableció la composición de tierras como una manera de titularizar -en forma privadatierras mediante un procedimiento judicial en el que los interesados debían demostrar su ocupación y uso, o bien denunciar un terreno como vacante y reclamar la realización de un remate en subasta pública por parte de los cabildos. Este procedimiento, muy dependiente del control del poder político local, habilitó la apropiación fraudulenta de tierras incluyendo sobre todo las de los indígenas. Finalmente, a partir de mediados del siglo XVIII se oficializó otro procedimiento para legalizar el dominio de las tierras vacas o realengas: la "justa prescripción", que otorgaba derechos a quienes pudieran demostrar la ocupación previa y antigua posesión. A los indígenas se les reconoció la posibilidad de prescripción de la propiedad colectiva en sus territorios como "poseedores inmemoriales" (Cueto, 1989). Sin embargo, y paralelamente, existieron casos en Cuyo de propiedad a título individual reconocida a indígenas desde el siglo XVII, al parecer relacionados con servicios militares en la frontera sur (Escolar, 2020). Desde principios del período independiente se presionó para liberalizar el acceso privado a la tierra y el fisco se apropió tanto de las tierras vacantes como de propiedades de la iglesia y, al parecer, de tierras indígenas aunque no se verifica una legislación directa al respecto y en Guanacache los laguneros continuaron invocando la legislación indiana durante el siglo XIX (Escolar, 2013, 2015). Aunque con cambios formales, tanto la adjudicación de tierras por servicios al estado o premio militar y los denuncios de tierras para los criollos y la propiedad individual y colectiva indígena, argumentada esta última con las figuras de posesión inmemorial o el status reduccional de la colonia, subsistieron en Mendoza hasta avanzado el siglo XIX (Cueto 1988, 1989; Escolar 2013, 2020). También en 1822 a nivel nacional y en 1853 a nivel local se intentaron proyectos de enfiteusis que, aunque fracasaron en términos generales, fueron invocados en posteriores litigios (Cueto, 1988). Hacia fines de 1860 se sumó la adscripción de tierras baldías para el sustento de instituciones públicas mediante su arrendamiento. $\mathrm{Y}$ entre 1874 y principios del siglo XX se desarrollaron algunas colonias agrícolas en la frontera indígena del sur de Mendoza y también en el norte de la provincia, con inmigrantes europeos (Mata Olmo, 1992; Massini Calderón, 1994). Sin embargo, la situación dominial en la mayor parte del territorio era bastante caótica -en el área de Guanacache lo es hasta la actualidad, en que los títulos de diversa índole inscriptos superan en más del doble la superficie real- dando pie, junto con el manejo político del sistema judicial, a toda clase de maniobras por parte de los miembros de la elite mendocina para generar derechos de propiedad. 
1. 810 leguas cuadradas -una legua cuadrada en Argentina equivale a $26,998.416 \mathrm{~km} 2$, o 2699,8416 hectáreas.

\section{La merced real del cacique Sayanca}

En octubre de 1895 el ciudadano francés Jules Watteau comenzó a publicar en el diario mendocino Los Andes una serie de anuncios reivindicando una supuesta merced real de tierras otorgada al cacique huarpe Diego Sayanca en 1713. El territorio reclamado, de 1500 leguas en Mendoza, San Juan y San Luis, tenía su mayor extensión en Mendoza, abarcando aproximadamente un cuarto de la provincia: 2.186 .871 hectáreas, ${ }^{1}$ de las cuales 69.370 ha eran tierras cultivadas, de pujante desarrollo agrícola y urbano. Incluía la totalidad o parte de los departamentos del centro, norte y este de la provincia: Lavalle, San Martin, Junín, Maipú, Guaymallén, Rivadavia, La Paz y Santa Rosa; aunque se extendía también a una apreciable porción de las provincias de San Juan y San Luis. La mitad de esta área estaba integrada por las Lagunas de Guanacache y su árido entorno o travesía, considerada desde siempre el territorio de refugio y supervivencia de los huarpes, un pueblo supuestamente desaparecido hacia el siglo XVII.

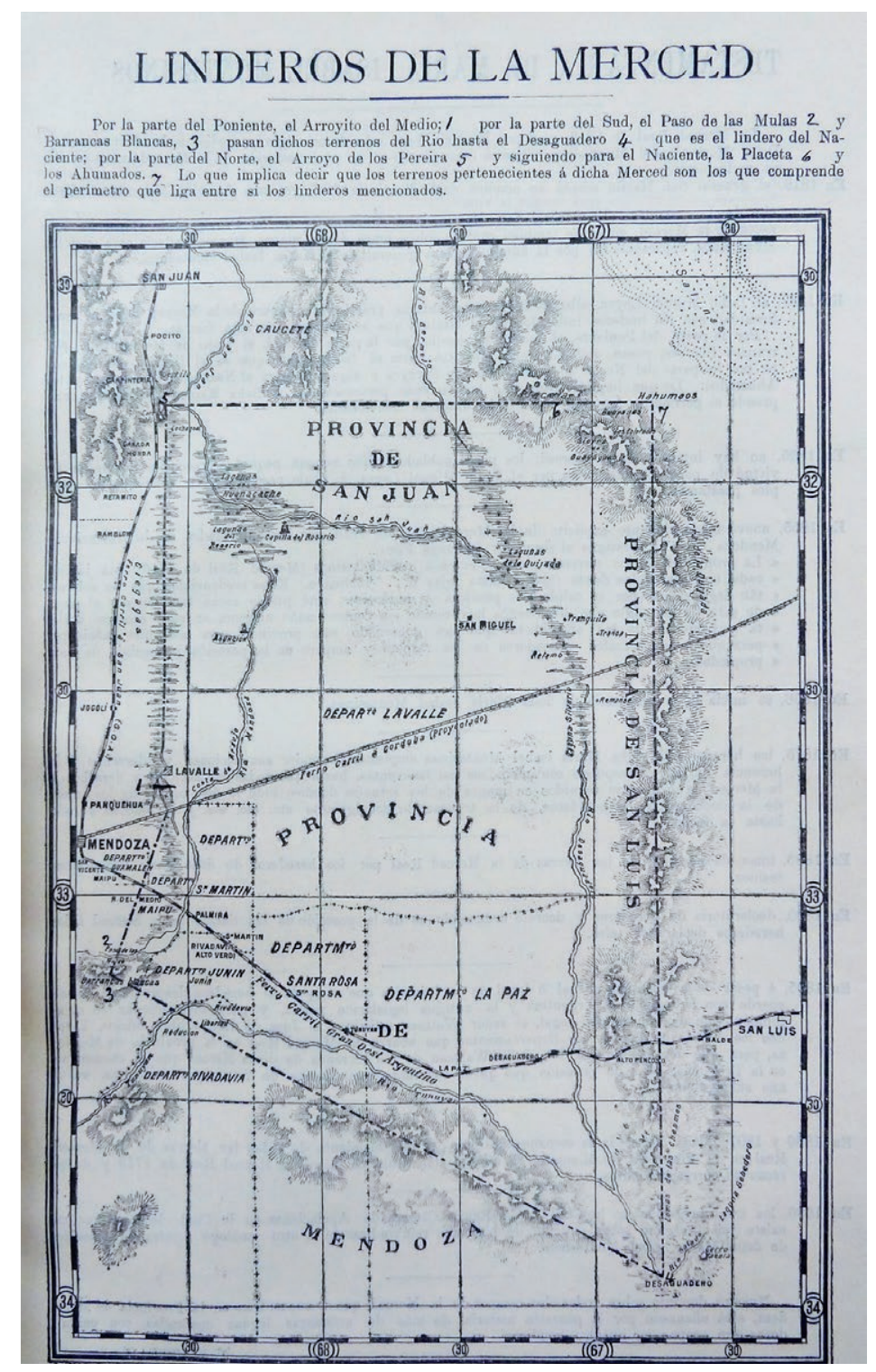

Figura 1. "Sucesión Montesinos. Bornes et limites de la Merced Réal en 1713". Sucesión Montesinos, Watteau s/f. 
A pesar de nuestra compulsa documental no hemos podido hallar datos sobre el arribo de Watteau a la provincia de Mendoza. Sólo sabemos que hacia la década de 1890 se presentó como apoderado de la merced aduciendo la compra de la mayoría de la sucesión a los herederos del cacique Sayanca, los Montesinos, intimando a pagar derechos de explotación a los ocupantes -teóricamente ilegales. Los textos de las solicitadas también declaraban prohibido "el corte de leña, rodrigones y maderas en campos que fueron de los Montesinos, sin autorización expresa del que suscribe" e invitaban a los interesados a negociar permisos de corte en su oficina del centro de la ciudad de Mendoza. A continuación los conminaba a "intercambiar ideas al respecto y ponernos de acuerdo sobre medidas que serán de común interés", agregando que "no hay propósito por nuestra parte de desalojar a nadie, sino de entendernos con todos de un modo equitativo". ${ }^{2}$

Aunque hace casi veinte años había escuchado los primeros comentarios sobre el cacique Diego Sayanca y su merced real, encontré la primera mención a Watteau en el Archivo del Ministerio de Relaciones Exteriores de Chile. ${ }^{3}$ Había hallado primero una referencia solitaria en Internet que mencionaba la existencia de la merced en dicho archivo. Posteriormente, en una visita a Santiago fui a buscarla. ${ }^{4}$ Cuando en lugar de un escueto y ajado papel la funcionaria acomodó en la mesa un par de gruesas cajas percibí que el asunto era mucho más complejo de lo que esperaba y que, por alguna razón, había concitado una preocupación diplomática hacia fines del siglo XIX y principios del siglo XX. Al revisar las carpetas se observaban mapas, recortes de periódico, cartas e informes en español y francés que denotaban un fluido intercambio de Jules Watteau con la legación francesa y chilena, a las que pedía ayuda para hacer valer los derechos de la merced real. Años más tarde pude hallar también los legajos sobre el tema en los archivos diplomáticos franceses, los que ampliaron la información al respecto en los archivos chilenos.

La historia de la merced se remonta supuestamente a 1713, cuando un corregidor de Mendoza, Thomás de la Llana, habría reconocido al cacique Diego Sayanca los territorios de Guanacache por sus servicios, presumiblemente militares, en la entonces frontera pehuenche del dominio colonial hispano en Cuyo. Aunque la autenticidad de la merced fue duramente cuestionada, en particular por un estudio realizado por la Universidad Nacional de Cuyo bajo la dirección de Juan Draghi Lucero en 1961 (Cornejo Lencina, 1961), hay indicios que permiten pensar que tal vez hubo un documento original que fue copiado para ser preservado, aunque con errores (Escolar, 2019). También existe plausibilidad histórica, en el sentido de que hay menciones a mercedes de tierras y cargos a caciques del centro y norte de Cuyo por servicios militares en la frontera sur de principios del siglo XVIII (Escolar, 2019). Inicialmente los caciques Sayanca figuran en los registros de encomiendas de Guanacache, iniciando con Pedro Callanga en 1618 -a 57 años de la fundación de Mendoza-, siguiendo con Don Francisco y su heredero Diego hasta $1648^{5}$ y luego reapareciendo en las fuentes con Don Pascual entre 1691 y $1708 .{ }^{6}$ El cacique Diego que habría recibido la merced sería el hijo de Pascual (Morales Guiñazú, 1961: 32). Con posterioridad se pierde el rastro del linaje aunque encontramos menciones a personas de apellido Sayanca en algunos documentos (Escolar, 2019: 147), además de la merced y el testamento de Jacinto Sayanca de 1752. Precisamente en una mensura de 1747 se menciona la "estancia" del cacique Jacinto Sayanca (Cornejo Lencina, 1961: 28). Desde principios del siglo XIX hay dos linajes distintos que se proclaman descendientes del cacique Diego. Uno reclamado por Narciso Leyes, habitante de las Lagunas, como supuesto esposo de una descendiente que logró protocolizar el título que aparentemente estaba en
2. Los Andes, 11 y 29 de octubre y 1 y 6 de noviembre de 1895: "Prohibición" y "Aviso a los ocupantes de la Sucesión Montesinos-Sayanca”, respectivamente.

3. AMREC, Fondo Argentina, Vol. 16o. Sucesión Montesinos.

4. Agradezco a Rolf Foerster por su acompañamiento en el acceso a la documentación.

5. En 1618 Pedro Callanga era uno de los tres caciques de la encomienda concedida al capitán Juan Ortiz de Urbina de los "laguneros" de la tierra de Aguartaques (Espejo, 1954: 53). En 1648 la encomienda ya citada incluía al cacique don Francisco Sallanga y su heredero Diego de veinte años de edad, de los naturales de las Lagunas de las Quijadas (Espejo, 1954: 129-30). Morales Guiñazú (1938:19-20) dice que en un documento de indios remitidos a Chile de 1645 en el Archivo Histórico de Mendoza figuraba el cacique don Francisco Sallanca y su hijo Diego.

6. Desde 1691 hasta 1708 Don Pascual Sayanca aparece en registros de encomiendas de las Lagunas. 
7. AHM, carp. oo1, doc. 16.

8. Defensa realizada por el Defensor de pobres y ausentes a los indios Laguneros, AHM, Carpeta 575 bis, doc. 17 y Copia del Esped [...] de D. Juan Escalante en [...] los naturales de las Lagunas [...] de un decreto del Gobierno [...] do gracia de terrenos en favor de [...] rales i del Testamento del Casique [...] Don Jacinto Sayanca en 1752. Archivo de Juan Nievas.

9. Domingo Villegas con Maximino Segura y Victor Albino denuncian un terreno en Villa del Rosario, Mendoza, 1 de enero de 1865 . AHM, Carpeta 120, Doc. 19.

10. Defensa realizada por el defensor de pobres y ausentes a los indios laguneros. AHM, Carpeta 575 bis, Doc. 17. Mendoza, 10 de mayo de 1879 .

11. Informe de Enrique Quiroga de 10 de agosto de 1892. En cumplimiento del encargo del gobernador de la provincia de reconocer los terrenos al sur de las Lagunas de Huanacache sobre el cual el gobierno de Mendoza pretende tener dominio. AHSJ, Fondo Histórico, Tomo 470. Fs. 300-305.

12. Debenedetti, S., \& J. Pozzi (1925). Diario de la XXla Expedición a las Lagunas de Huanacache en 1925 del Museo Etnográfico, dirigida por Salvador Debenedetti. Archivo Fotográfico y Documental del Museo “Juan Bautista Ambrosetti”. (Ms.)

13. Pozzi, J. (1925). Diario de la XXI Expedición a las Lagunas de Huanacache en 1925 del Museo Etnográfico, dirigida por Salvador Debenedetti, cuaderno 2. Buenos Aires, Archivo Fotográfico y Documental del Museo "Juan Bautista Ambrosetti". su poder en 1819 a nombre de su esposa Isabel Montecinos y Sayanca. ${ }^{7}$ Otro ligado a José Joaquín Sayanca, quien fuera un funcionario del gobierno de Mendoza en 1820-1822, cuyo hijo Manuel Emiliano Sayanca formó posteriormente parte de la elite política mendocina en el siglo XIX. Nacido en 1834 fue un famoso educador, director del principal colegio y diputado provincial hacia 1880 (Escolar, 2019: 148). Sus descendientes continuaron litigando con éxito por tierras de la merced, vendiéndolas en distintos departamentos de Mendoza y hasta la actualidad el autodenominado Inca Joaquín Sayanca sostiene numerosos litigios y mantiene el archivo familiar.

Ahora bien, esta merced de Diego Sayanca y un testamento de su nieto Jacinto Sayanca, donde menciona que se lega la misma a los indios del lugar, fueron utilizados al menos desde la primera mitad del siglo XIX por los laguneros como una de las fuentes de sus derechos territoriales. Encontramos transcripto el testamento como parte de la Defensa de los Naturales de las Lagunas efectuada por Juan Escalante en la década de $1830 .^{8}$ También, en los autos del proceso de denuncia de tierras en San Miguel de las Lagunas por parte de Víctor Alvino, Enrique y Maximino Segura entre 1865 y $1868 ;{ }^{9}$ y además en el petitorio presentado por los laguneros al gobierno de Mendoza en 1879.10 Asimismo, copias del testamento se encuentran solas o junto con las de los mencionados expedientes judiciales en algunos archivos familiares de actuales o antiguos habitantes de las Lagunas.

Como describe una pericia de 1892, en el marco de un conflicto limítrofe que involucraba a Guanacache entre las provincias de San Juan y Mendoza, justo dos años antes de que comenzaran los planteos de Watteau,

Los pobladores del territorio lagunero de Mendoza pretenden ser propietarios del terreno [...] fundando su pretensión en un título emanado del soberano español el cual en el siglo pasado hizo a los indios pobladores de aquel lugar una concesión de tierras en dicho territorio [...]. ${ }^{11}$

Años más tarde, en 1925, durante una expedición arqueológica de la Universidad de Buenos Aires a las Lagunas de Guanacache, Salvador Debenedetti rescató la importancia local de las memorias del cacique Sayanca al consignar que Florencio Ferreyra, un poblador de prestigio, era considerado su descendiente. ${ }^{12}$ Días más tarde José Pozzi, el acompañante de Debenedetti, señalaba que otro lagunero, Esteban González (a) "El toro negro", quien "Parece indio, usa chiripá rayado de color rojo, café y azul" decía que "tiene en su poder una copia de la escritura de Sayanca en la cual dona a los habitantes de esta región 400 leguas cuadradas, cuyo centro sería la actual capilla del Rosario."13 $\mathrm{Al}$ año siguiente Alberto Castellanos relata que frente a la Capilla del Rosario de Las Lagunas, el centro simbólico de Guanacache -en cuyo cementerio está enterrado el cacique Jacinto Sayanca- un poblador le recitó su testamento (Castellanos, 1926).

Diversos estudios recientes en Argentina han sugerido la existencia de prácticas de recopilación y atesoramiento de documentos coloniales y republicanos como prueba de derechos y articuladores de memorias indígenas, además de en Cuyo, en otros sectores del centro y norte del país durante los siglos XIX y XX (Fandos, 2007; Escolar, 2007, 2013, 2015; Rodríguez, 2011a; Tell, 2012; Escolar y Rodríguez, 2019). Aunque en estrecha relación con esos procesos, hasta ahora el único caso conocido de una merced real de tierras invocada y utilizada judicialmente durante el período de consolidación del estado nacional moderno y la actualidad por una comunidad indígena en el territorio 
argentino era el de Amaicha del Valle, en Tucumán. El antropólogo Alejandro Isla mencionaba que ésta era "la única comunidad en Argentina que conserva el título de la Merced Real sobre sus tierras otorgada en el siglo XVIII" (Isla, 2002: 8) y que los comuneros guardaban "una viva y orgullosa memoria de ese documento [...] emblema político para el reclamo de sus tierras" (Isla, 2002: 9). Esto es comparable, aunque con importantes diferencias, a lo ocurrido con la merced real de Sayanca en las memorias y las luchas judiciales de los laguneros, no obstante su cuestionada autenticidad y el hecho de que aparentemente fue otorgada a título individual.

La autenticidad de la merced de Amaicha también ha sido cuestionada por algunos estudios (Sosa, 2015a, Sosa, 2015b). Sin embargo, lo más significativo para nuestro análisis no es su autenticidad sino su valor social y uso judicial. Si observamos el caso de los "títulos primordiales" de comunidades indígenas mesoamericanas, la (in)autenticidad es un concepto debatible considerando el valor performático para las identificaciones, memorias y luchas judiciales indígenas y el hecho de que eventualmente fueron considerados válidos por el Estado (Escolar, 2019). ${ }^{14}$

Los documentos de los caciques Sayanca forman parte, en efecto, de los "archivos huarpes" en manos de familias laguneras que he analizado en otros trabajos (Escolar, 2013, 2015), sobre los que basaron las luchas judiciales de las tierras de Guanacache y, en parte, sus propias identificaciones indígenas. La supuesta falsificación de la Merced Real fue el principal baluarte para deslegitimar esos reclamos (Escolar, 2019). Esta discusión y sus efectos legales continuaron a lo largo del siglo XX e inclusive hasta la actualidad, siendo su hito principal el conjunto de estudios realizados por la Universidad Nacional de Cuyo en la década de 1950, dirigido por Juan Draghi Lucero, respetado folclorista, escritor e historiador mendocino. Los peritajes históricos y caligráficos del informe concluyeron que la merced era "una burda falsificación fraguada por 1818-19." (Cornejo Lencina, 1961: contratapa), "un timo judicial que ha conmovido a Mendoza durante más de 100 años [...] al amparo de notarios inescrupulosos, funcionarios indolentes, magistrados venales y abogados voraces" (Cornejo Lencina, 1961: 4).

La Merced Real, al contrario que el testamento, no se encuentra en ninguno de los expedientes antedichos sino que habría sido introducida subrepticiamente en el Archivo Histórico y Administrativo de la provincia a mediados del siglo XX, según un perito (Zuloaga, 1961: 26). ${ }^{15}$ Esto alimentaría la presunción de su falsedad, pero no daría cuenta del valor político e incluso legal que tuvo y eventualmente le fue reconocido. En efecto, más allá del cuestionamiento a la autenticidad del documento del Archivo Histórico de Mendoza, los detractores de la merced no mencionaron nunca las prácticas de los laguneros que reclamaron por sus tierras a lo largo del siglo XIX y principios del XX utilizando ese, entre otros instrumentos. Menos aún las memorias colectivas indígenas que se articularon en torno a esos documentos a lo largo de los siglos XIX y XX. Referentes locales movilizaron judicialmente esos textos e incluso presionaron por su consideración legal a menudo lográndolo. Esos documentos fueron clave en la producción legal de la verdad a través de usos performativos y pragmáticos que, en un punto, no difieren de lo efectuado por los actores no indígenas en reclamo de propiedad sobre los mismos espacios (Escolar, 2019).

En torno a la Merced Real del cacique Sayanca se desarrollaron entonces diversos usos. Primero, como mencioné, en diversas ocasiones los laguneros recurrieron a ella como uno de los instrumentos para la defensa judicial de
14. Estos títulos -textos y pinturas producidos por los propios indígenas entre los siglos XVI y XVIIIfueron eventualmente tomados en consideración por tribunales republicanos. Aunque buena parte de la literatura especializada, de hecho, los desestimó por apócrifos, tal vez en la mayoría de los casos el objetivo de su confección no habría sido falsificar sino suplir la pérdida de documentos originales, 0 incluso crearlos como documentos legítimos según las formas escriturales que consideraban apropiadas (Gibson,1975; Menegus Bornemann, 1994; Florescano, 2002, Romero Frizzi, 2011).

15. Sin embargo, pese a su misterioso y probablemente tardío origen el documento fue clasificado en la Carpeta oo1 del archivo, al menos metafóricamente, como uno de sus documentos fundacionales. AHM, Carpeta 001, Doc. 16. Merced Real a favor del cacique Diego Sayanca. Mendoza, 1 de febrero de 1713. 
16. Su padre era Domingo Montesinos y Sayanca y ella se presenta en su testamento como Isabel Montesinos y Sayanca. AMREC, Fondo Argentina, Vol 16o: Sucesión Montesinos. Memorial presenté a Monsieur le Ministre de France a Buenos Aires, 1898. Copia del título de la sucesión Montesinos, Fs. 7.

17. AMREC, Fondo Argentina, Vol 16o. Sucesión Montesinos. Memorial presenté... En este expediente se incluyen, entre otros documentos, una copia del título de las tierras de la merced y su protocolización, junto con otros elementos probatorios de la sucesión. Se dice que concuerda esa copia con la existente en el expediente seguido por Don Miguel Leyes, albacea de la testamentaría Sayanca-Montesinos.

18. AMREC, Fondo Argentina, Vol 16o. Sucesión Montesinos. Memorial presenté..., fs. 4-6. declara haberse presentado, siempre con sus protocolizaciones y certificaciones: el poder general conferido por San Martin en Paris a Dominga Bouchard de Balcarce, el traslado otorgado por ésta al Gobernador de Mendoza de entonces, Pedro Pascual Segura, y finalmente el de este éste a Felipe Zorraindo.

19. AMREC, Fondo Argentina, Vo 16o. Sucesión Montesinos. Memorial presenté.., fs. 3-4. Faustina Núñez, de la línea sucesoria de los Montesinos-Sayanca, adjunta un escrito de su madre donde dice que la donación a San Martin se hizo con cargo de que el General debía costear el sacar un testimonio de todas las tierras pertenecientes al cacique Diego Sayanca. Para ello debía obtener los documentos originales de los archivos de la República de Chile porque los que tenía estaban rotos e ininteligibles.

20. Al no hallarlo en los archivos el abogado de los sucesores de los Montecinos-Sayanca trajo el título de donación que obraba en poder de sus representados, el cual finalmente fue dado por válido. AMREC, Fondo Argentina, Vol 16o. Sucesión Montesinos. Memorial presenté..., fs. 6 .

21. AMREC, Fondo Argentina, Vol 16o. Sucesión Montesinos. Memorial presenté..., fs 6-7. sus tierras. Segundo, supuestos o reales herederos del cacique o del primer apoderado mencionado en los documentos, Miguel Leyes, reclamaron total o parcialmente las tierras que abarcaba la merced. Tercero, particulares compraron derechos de tierras o intentaron legalizar sus títulos sobre la base de supuestas compras a herederos del cacique (Cornejo Lencina, 1961: 65). Estas ventas se hacían bajo la figura de "derechos y acciones"; es decir, sin la escritura del terreno sino mediante un documento de cesión de herencia certificado por escribano público. Pero, eventualmente, herederos de una época posterior podían desconocer ventas anteriores exigiendo dinero a los mismos compradores, a sus sucesores o a terceras personas que hubieran comprado a los mismos. Lo habitual era que el inicio de las litis se produjera cuando alguien realizaba trabajos de cierta importancia en un lugar, valorizando las tierras, para obligarlos a negociar a riesgo de perder lo invertido (Cornejo Lencina, 1961: 69).

\section{La cruzada inmobiliaria de Jules Watteau y la controvertida constitución de la propiedad en el norte de Mendoza}

En las solicitadas publicadas por Watteau -algunas de las cuales ocupaban una porción muy apreciable de los tabloides- se resumía la historia judicial del documento de la Merced Real que era esencial para sustentar los derechos esgrimidos. Estas explicaciones se explayaban mucho más en las memorias presentadas a la embajada de Francia en Buenos Aires y a la cancillería chilena que, como veremos, intervinieron directamente en el asunto.

Según Watteau los derechos que representaba provenían de la línea sucesoria de la ciudadana chilena María Isabel Montesinos de Sayanca, ${ }^{16}$ quien habría protocolizado el título en 1818 en la justicia mendocina. Esto había ocurrido a raíz de que ese año Montesinos donó un terreno de tres leguas de la merced al General San Martin, quien había sido hasta el año anterior gobernador de Cuyo, en gratitud por los servicios prestados a la causa libertadora. ${ }^{17} \mathrm{La}$ donación, reconocida por la provincia, fue utilizada para obtener en forma efectiva los derechos del resto de la merced. Mencionada en autos como extraviada, fue reconocida en1849 por el apoderado del Gral. San Martín, Felipe Zorraindo, ${ }^{18}$ en un acta de conciliación firmada con la hija y apoderada de Isabel Montesinos, quien acordó un deslinde de las tres leguas de tierras donadas a San Martín donde se fundaría la villa que actualmente lleva su nombre. ${ }^{19}$ En 1854 se inició una mensura de los "campos pertenecientes a Montesinos y Sayancas" que el fiscal hizo paralizar en espera de hallar el documento original de donación. ${ }^{20}$ Pero en 1856 dio por probada la posesión de las tierras de la merced durante más de un siglo por parte de los sucesores del cacique Sayanca, por lo que ordenó se continuaran las diligencias de mensura para deslindar la Villa de San Martin..$^{21}$ En 1866 se inició la testamentaria de Montesinos sobre el resto de las tierras de la merced produciéndose un intento de toma de posesión en 1883. En 1890 se efectuó la declaratoria de los herederos y en 1891 el Juez de Letras Castillo dictó el decreto ordenando se dé la posesión de la tierra a los mismos.

En 1895 Jules Watteau, como apoderado de la merced real por parte de los descendientes de Isabel Montesinos, peticionó al Juez de Letras renovar los decretos de toma de posesión judicial, lo cual este efectuó librando oficios a los Jueces de Paz de los departamentos que abarcaba el título. Eso dio inicio a la publicación de proclamas de Watteau en los periódicos e intimaciones judiciales a los ocupantes de las tierras, muchos de ellos con otros títulos de propiedad, a pagar los derechos de uso, lo cual abrió una serie impugnaciones 


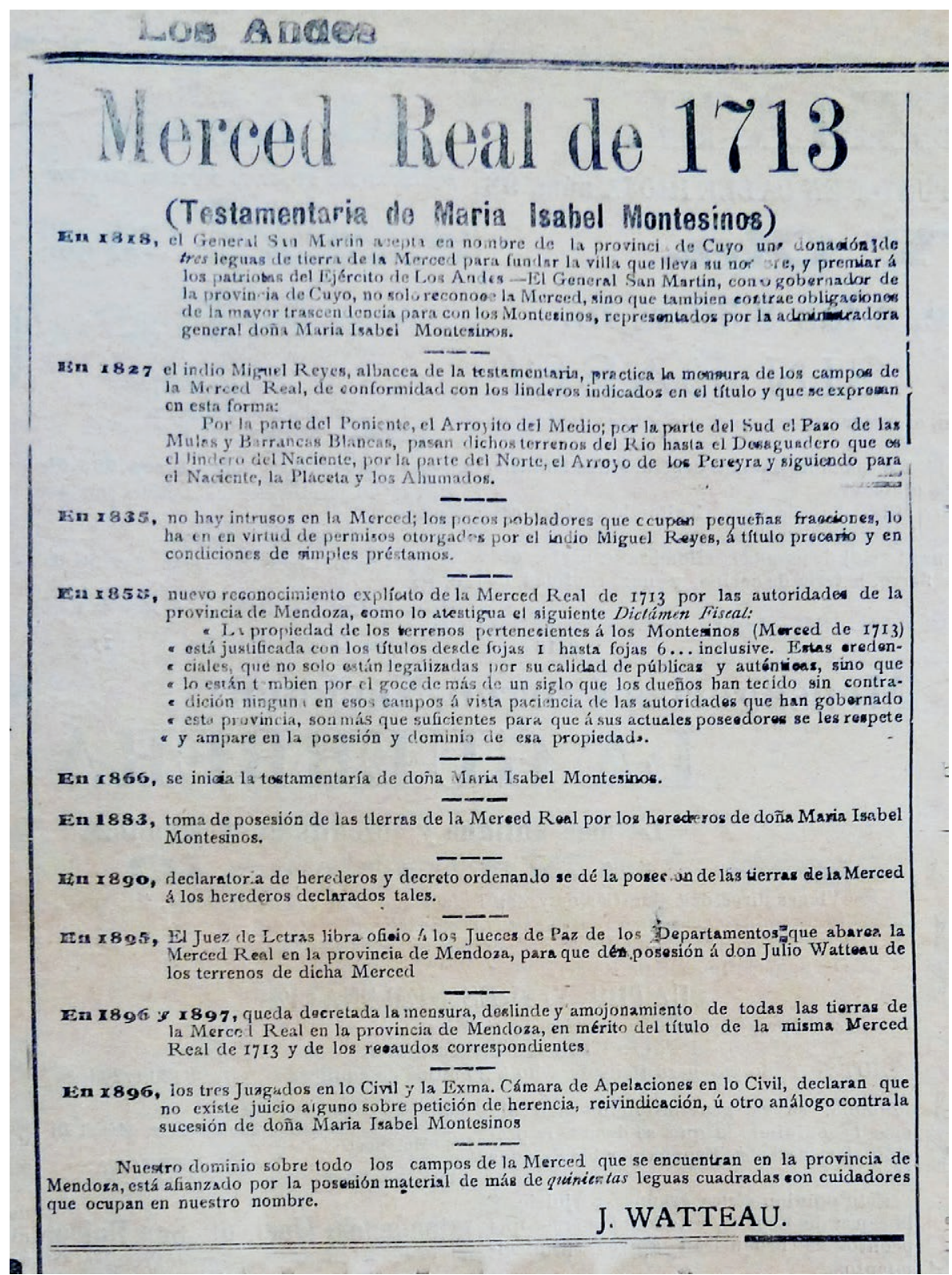

Figura 2. "Merced Real de 1713" en Los Andes, 20 de noviembre de 1897.

y litigios en su contra. ${ }^{22}$ Lo que fue considerado por una creciente legión de detractores como la más grotesca maniobra especulativa de que se tuviera noticia, en una provincia no poco habituada a las mismas, generó una crisis de proporciones que se instaló como un tema central en la prensa de la época: además del diario Los Andes, otros como El Debate, El Diario, El Porvenir y los porteños La Nación y La Prensa se hicieron eco, o directamente intervinieron en el conflicto. La demanda se judicializó y atravesó una conspiración de un amplio arco de miembros de los tres poderes del estado que, luego de todo tipo de presiones, lograron que la causa quedara sin juez que interviniera en la misma a partir de la inaudita recusación de todos los magistrados de la provincia. Luego, formaron un tribunal especial -e ilegal- que determinó que Watteau recurriera a la justicia federal, llegando a la Corte Suprema de la Nación y a la intervención oficial de las embajadas de Francia, Chile, y Suiza, aspecto que exploraremos con más detalle en un futuro trabajo. Por ahora nos concentraremos en las repercusiones locales de este conflicto, que desnudó
22. Los Andes, 26 de noviembre de 1897, 2. "Demanda contra D. Carlos S. Varas. Interdicto de recobrar posesión". 
23. Los Andes, 11 de octubre de 1895. "Vista Fiscal".
24. AMREC, Fondo Argentina, Vol. 16o, Sucesión Montesinos. Resume des 11 Annexes qui accompagnent le "Memorial" presenté a Monsieur le Ministre de France, a Buenos Aires, en décembre de 1898, págs. I-II.

25. Los Andes, 29 de octubre y 1 de noviembre de 1895 .

26. AMREC, Fondo Argentina, Vol. 16o, Sucesión Montesinos. Résume des 11 Annexes..., pág. III.

27. AMREC, Fondo Argentina, Vol. 16o, Sucesión Montesinos. Résume des 11 Annexes..., pág. IV. Los Andes, 6 y 22 de noviembre de 1895 .

28. AMREC, Fondo Argentina, Vol. 16o, Sucesión Montesinos. Résume des 11 Annexes..., pág. IV.

29. Los Andes, 20 de noviembre de 1897. "Contra El Diario. Acusación criminal."

30. La práctica de retener autos y documentos judiciales parece haber sido muy extendida en Mendoza desde el período colonial y estuvo asociada a la venalidad o debilidad del sistema judicial y a la falsificación o robo de expedientes. Esto habilitó dos estrategias, ligadas ambas al ocultamiento de documentos supuestamente probatorios de propiedad: una, de parte de los particulares ante la necesidad de resguardar sus derechos frente a otros particulares que con mayor poder político e injerencia en el poder judicial podían hacer desaparecer los instrumentos legales presentados.

31. Ponce, C. y J. Watteau (1898). Contra El Debate: Acusación criminal" en Los Andes, 8 de octubre de 1898. el vicio de legitimidad en el que estaba basada la propiedad de la tierra en la región y las contradicciones de un proceso colonial interior que había continuado mucho más allá de la emancipación nacional.

Cuando comenzaron a hacerse públicos los reclamos de Watteau se generaron airadas críticas a la actuación del autoproclamado apoderado. Un artículo periodístico evocó sus maniobras como parte de una larga tradición mendocina de fraude basada en la descendencia del cacique. Reproducía el escrito de un denominado "asesor fiscal" designado ad hoc por el gobierno de la provincia, Marcos Flores, quien afirmaba que Watteau estaba invadiendo campos fiscales o particulares por la fuerza, engañando o amenazando, y persiguiendo a quienes cortaran madera. ${ }^{23}$

El asesor fiscal Marcos Flores escribió una autodenominaba "vista fiscal", que apelaba al Art. 2479 del Código Civil Argentino, argumentando en favor de los actuales poseedores, quienes estarían amparados "por el hecho y por el derecho" y por lo tanto no podían ser desalojados, aún en el supuesto de que existiera orden de un juez frente a lo cual podían incluso repeler el intento mediante el uso de la fuerza. Al día siguiente el dictamen de la ilegal Vista Fiscal en contra de la Merced Real se trasformó en decreto del Gobernador Francisco Moyano, sin haber pasado por tamiz legislativo o judicial alguno. ${ }^{24}$

Días más tarde el propio Watteau en el diario Los Andes cuestionó ácidamente tanto la actuación del fiscal ad hoc como el decreto de Moyano. ${ }^{25}$ Según Watteau, la causa de estas flagrantes violaciones de los principios constitucionales era que tanto el gobernador, como prácticamente todo su gabinete, poseían grandes porciones de tierra dentro de la merced. En noviembre el presidente de la Cámara de Diputados, Isaac Godoy, en el diario oficial El Porvenir, llamó a "combatir la sucesión Montesinos con todos los medios al alcance del gobierno". ${ }^{26}$ La dirección de Los Andes denunció un segundo decreto del gobierno, basado en el informe del asesor fiscal, como una injerencia directa e inadmisible del gobierno en la justicia. ${ }^{27}$

En 1896 los tres juzgados en lo civil y la Cámara de Apelaciones declararon que no existía juicio alguno sobre petición de herencia o reivindicación contra la sucesión de doña María Isabel Montesinos y al año siguiente se decretó la mensura, deslinde y amojonamiento de todas las tierras de la merced real en la provincia de Mendoza. ${ }^{28}$

En noviembre de 1897 Watteau se defendió, a través de Los Andes, de las acusaciones del director de El Diario, Julio Leónidas Aguirre, de retener expedientes judiciales y robar fojas. El francés respondió que mantenía en su poder los autos, supuestamente dentro de los márgenes que le otorgaba el derecho, "a fin de ponerme a cubierto de los frecuentes robos de fojas y adulteraciones de autos muy factibles en nuestros Tribunales, por medio de copias auténticas o duplicados de los mismos autos" ${ }^{29}$ Estos robos eran moneda corriente en Mendoza desde tiempos pretéritos, como la desaparición de expedientes bajo diversas excusas. ${ }^{30}$ En otro artículo periodístico, respondiendo a quienes exigían la merced original, aducía que sus copias eran suficientes porque era habitual la falta de los originales por robo "bien sabido es que el terremoto (de 1861) fue ocasión y pretexto para el vandalaje impune en los archivos de Mendoza". ${ }^{31}$

Como dirá años después en su informe Cornejo Lencina (1961: 9) “hombres de todos los colores y posiciones políticas han metido la mano y dejado sus 
huellas en esa bolsa robada" de la merced Sayanca. Las acusaciones de Watteau tocaron algunas fibras evidentemente sensibles de las elites locales, de distintas facciones, que el 15 de octubre del mismo año publicaron en El Debate la llamada a una reunión en la notaría de Salvador B. Reta para formar un "Centro de Defensa" contra las reivindicaciones del apoderado de la merced. ${ }^{32} \mathrm{La}$ Comisión Provisoria firmante estaba integrada por destacadas figuras locales y grandes propietarios, entre ellos: Pedro y Gregorio Guevara; Salvador, Pastor, y Benjamín Reta; Nicolás R., Ramón y Belisario Cano; Juan A. Arnulphi, José A. Delgado, Ricardo Palencia, Diógenes Vargas, José Néstor Lencinas, Ricardo Baez, Julio Leiton, Lucas Simonovich, José Palma y Exequel Marin.

Los conflictos continuaron y el 14 de diciembre de 1897 Watteau publicó otra de sus habituales solicitadas ampliando las denuncias contra sus contendientes, en la cual sugería el carácter fraudulento de la generalidad de las propiedades en el norte de Mendoza. "Audaces especuladores", escribió, se habían repartido la tierra "a la marchanta", tarea sencilla para la elite mendocina, porque "con un escribano obediente y un agrimensor más complaciente aún, todo se hacía en Mendoza, en años anteriores". Los aventureros "vendieron las tierras colocando en sus títulos que habían comprado la fracción a herederos de Isabel Montesinos, y ahora esos mismos especuladores impugnan la validez de la Merced Real". ${ }^{33}$ Es decir, para legitimar sus propiedades hicieron un uso indirecto de la merced reconociendo la propiedad anterior de los Montesinos. Como insinuaba Watteau en el epígrafe que abre esta contribución, si denunciaban la falsedad de la Merced Real deberían también impugnar todas las propiedades que se sustentaban en supuestas compras a los Montesinos,

Esto pareció ser ya demasiado para sus numerosos enemigos. El 22 del mismo mes, El Debate anunció que el Senado había autorizado al poder ejecutivo a nombrar un fiscal ad hoc, el Dr. Ramón Videla (h), para la sucesión Montesinos. ${ }^{34}$ Watteau y su abogado y socio, Cesar Ponce, entablaron no menos de ocho acusaciones criminales por difamación contra El Debate y El Diario, los periódicos que fogonearon la campaña en su contra. ${ }^{35}$

El 28 de octubre de 1897 El Diario publicó artículos contra el Juez Petra, designado en la sucesión Montesinos, el cual es obligado a renunciar. El Debate continuó ridiculizando a Watteau, como citaba el propio francés en Los Andes, afirmando que sus gestiones se basaban en "antecedentes sospechosos, piezas truncas, relaciones falsas [...] la más peregrina embrolla judicial que registran los anales de nuestros embrollados tribunales." ${ }^{36}$ Luego la causa se frenó nuevamente, el 10 de noviembre de 1898 Watteau y Ponce presentaron una demanda a la Corte Suprema de Justicia porque hacía más de un año que no se le designaba Juez a la causa y no se le daba la posesión de las tierras. ${ }^{37}$

La escalada incluyó diversos actos de violencia que rápidamente derivaron en nuevas denuncias. Como estrategia de posesión, Watteau había designado "cuidadores" locales en algunos campos de las tierras que cabían dentro de la merced -casi todos en el área de las Lagunas- quienes eran en general ocupantes previos, con los que Watteau había negociado a cambio de algún dinero. En abril de 1896 colocó como cuidador, de unas tierras reclamadas por un tal Carlos Segundo Varas en San Martin, al anciano de 105 años José Herrera. Herrera había sido capataz de Don Miguel Leyes, el albacea de la testamentaría del cacique Sayanca hasta su muerte en 1837. Varas, inducido por la propaganda "brava e irresponsable de esta ciudad", acompañado de un peón y un capataz, incendió el rancho de Herrera y le dio latigazos desde arriba del caballo. ${ }^{38}$ Watteau denunció también que 40 hombres armados al mando
32. Ver EL Debate, 15 de octubre de 1897 (en Cornejo Lencina, 1961: 36).

33. Los Andes, 14 de diciembre de 1897. "A los ocupantes de tierras de la Merced Real de 1713”.

34. AMREC, Fondo Argentina, Vol. 16o. Sucesión Montesinos. Resume des 11 Annexes..., pág. IV.

35. AMREC, Fondo Argentina, Vol. 16o. Sucesión Montesinos. Resume des 11 Annexes Resume des 11 Annexe..., pág. V.

36. Ponce, C. y J. Watteau (1898). "Contra El Debate: Acusación criminal" en Los Andes, 8 de octubre de 1898 .

37. AMREC, Fondo Argentina, Vol. 16o. Sucesión Montesinos. Resume des 11 Annexes Resume des 11 Annexes..., pág. VI.

38. Los Andes, 26 de noviembre de 1897, 2. "Demanda contra D. Carlos S. Varas. Interdicto de recobrar posesión". 
39. AMREC, Fondo Argentina, Vol 16o. Sucesión Montesinos. Memorial presenté a Monsieur le Ministre de France a Buenos Aires, 1898 , f. 9.

40. AMREC, Fondo Argentina, Vol 16o. Sucesión Montesinos. Memorial presenté a Monsieur le Ministre de France a Buenos Aires, 1898 , f. 17.

41. AMREC Fondo Argentina, Vol 16o. Sucesión Montesinos. Carta de Manuel Ugarte a Tezanos Pinto, págs. 16-17: Manifiesta que son 30 los miembros con intereses en tierras de la merced, sin embargo en el listado presentado por Watteau en su reclamo de justicia a la embajada francesa, se postula que son 32 (ver Anexo I).

42. AMREC, Fondo Argentina, Vol 16o. Sucesión Montesinos. Memorial presenté a Monsieur le Ministre de France a Buenos Aires, 1898, f. 10.

43. La Prensa, 17 de noviembre de 1904. "En los tribunales mendocinos". del Subdelegado y dos camaradas del anterior gobernador Emilio Civit quisieron asesinar a una comisión encargada de demarcar las tierras para la toma de posesión, la cual incluía al oficial de justicia nombrado por el tribunal. ${ }^{39}$

Watteau y Cesar Ponce no estaban exentos de riesgos similares. Encontrándose Ponce en el Club Social, principal centro de reunión de las elites mendocinas, le dispararon con una carabina Winchester desde la ventana de una casa vecina. Mientras que a las oficinas de Watteau llegaban cartas amenazantes, en la casa de Gobierno se habría escuchado decir “¿Cuándo se matará a Watteau?”, “Qué hacen que no lo matan de una vez?". El hostigamiento provenía del gobierno circunstancialmente constituido, pero también del conjunto de familias oligárquicas que mediante una red de corrupción y nepotismo comandaban la provincia desde fines de la década de 1870, apropiándose de las tierras, el agua y la fuerza de trabajo de criollos pobres e indígenas. Esta elite era la fundadora de la moderna Mendoza, que sobre la base de esas apropiaciones había construido los oasis vitivinícolas desertificando el resto del territorio. Su cabeza era Emilio Civit, hasta hacía muy poco gobernador de Mendoza y en el momento ministro de Trabajos Públicos de la Nación. Como afirmaba Watteau, Civit era el líder político más fuerte en Mendoza y "el deux ex máchina" de la operación contra la sucesión Montesinos. ${ }^{40}$

Las quejas de Watteau, como hemos visto, se centraban en el corrupto sistema institucional de la provincia en su conjunto: los poderes ejecutivo, legislativo y, en particular, el judicial. Un sistema que suele considerarse, retrospectivamente, un modelo en el país sobre la imagen de la "institucionalidad mendocina" que, como mostraba Watteau, es más bien un mito fundacional de su sistema político. El poder legislativo, según Watteau, dominaba al de justicia ya que este abusaba de las facultades que la Constitución provincial otorgaba a la legislatura, de prestar su acuerdo para el nombramiento y ascenso de magistrados y de acusar y juzgar en juicio político a toda la magistratura provincial. Esa fue la base para obligar a la insólita maniobra de auto-recusación de todos los jueces y nombramiento de un fiscal ad hoc dependiente del ejecutivo. En este caso, la dependencia de los jueces del poder político se veía agudizada, según el francés, por el interés directo e indirecto que la mayoría de los funcionarios de los poderes ejecutivo, legislativo además de los propios miembros del judicial, tenían en la causa. Según el listado que el propio Watteau elevó a la embajada francesa, 32 de sus 36 miembros, o sus familiares directos, estaban implicados en propiedades dentro de la merced real. ${ }^{41}$

Las presiones al poder judicial por parte del gobierno, decía el apoderado, fueron "sin preocupación ninguna por las apariencias", ya que en Mendoza "las garantías constitucionales son un mito". 42 Estas apreciaciones no eran exclusivas de Watteau. En un artículo de La Prensa de Buenos Aires de 1904 se describe el estado venal y la falta de independencia del poder judicial de Mendoza. Una comisión de la legislatura provincial halló procedimientos ilegales de varios jueces durante los ocho últimos años y acusó al gobierno conservador de la época de Galigniana Segura de tapar el asunto. ${ }^{43}$

Además de las maniobras que hemos señalado, el fiscal ad hoc se habría excedido en su intervención en la prensa través de la publicación de su informe -vista fiscal- acusatorio de Watteau. También lo habría hecho al formar bajo el mando del ministro de gobierno un tribunal ad hoc con el juez de comercio, usurpando la jurisdicción originaria de la justicia penal que le correspondería al pleito por sus denuncias al estado por incumplimiento de sentencia e intento de asesinato. Watteau denunció el carácter secreto de este tribunal, debido a 
que no divulgaba sus actuaciones y no admitía su derecho a la defensa. ${ }^{44} \mathrm{El}$ procedimiento que, según denunciaba Watteau, pretendía revivir la inquisición era a todas luces inconstitucional, ${ }^{45}$ por lo que acusó al fiscal de haberse puesto al servicio de "mis pudientes y numerosos adversarios repartidos en todas las ramas del Estado de la Administración Pública Provincial, llámese Senado, Poder ejecutivo o Administración de Justicia".

En su presentación a la legación francesa y también a la chilena, cuya copia consultamos, Watteau adjuntó un listado de los miembros de los tres poderes del estado presuntamente afectados por la reivindicación; de ser cierto esto indicarían que la casi totalidad de los miembros de la legislatura y los funcionarios más altos de gobierno o sus familiares directos contarían con propiedades viciadas de legitimidad en las tierras de la merced. ${ }^{46}$ Watteau incluso aclaró que dicho listado no incluía a funcionarios locales menores, como subdelegados departamentales, jueces de paz o comisarios, muchos de los cuales también ocupaban tierras en el área de la merced real.

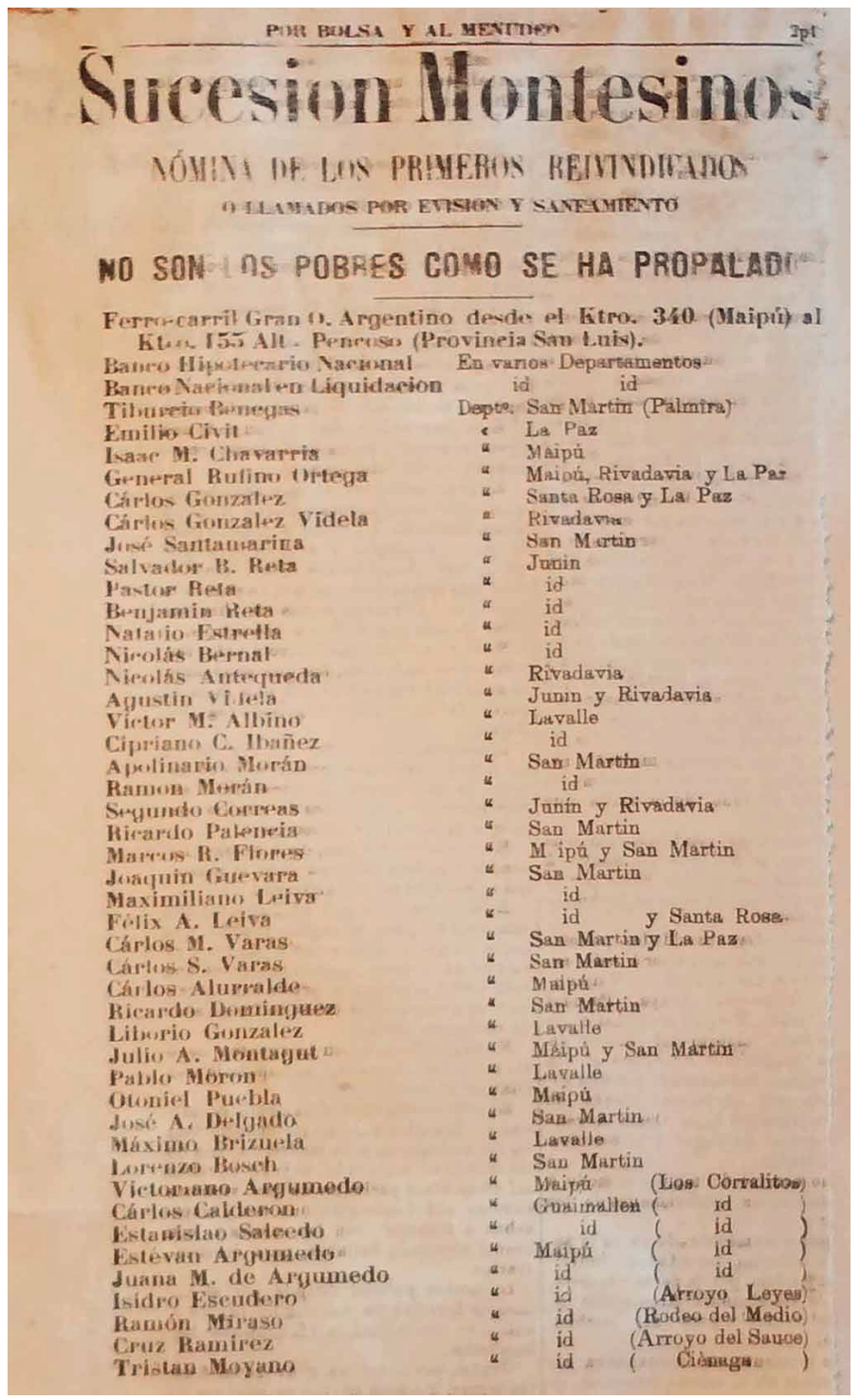

Figura 3. "Sucesión Montesinos: nómina de los primeros reivindicados" en Los Andes, 18 de noviembre de 1900.
44. AMREC, Fondo Argentina, Vol. 160. Sucesión Montesinos. Resume des 11 Annexes..., f. 10. "Jueces contra Watteau, Watteau sin juez", y ver también "Dossier Secret" -en el Memorial presenté a Monsieur le Ministre de France a Buenos Aires, 1898, f. 13 .

45. AMREC, Fondo Argentina, Vol. 160. Sucesión Montesinos. Resume des 11 Annexes..., f. 10. En la Constitución provincial de 1900 se elimina la independencia del poder judicial.

46. Liste des membres du pouvoir Exécoutif, du pouvoir Legislatif, fonctionnaires del' Adminitration etc., etc., affectés par notre Revendication des terres de la Sucession Montesinos. AMREC, Fondo Argentina, Vol 16o. Sucesión Montesinos. Memorial presenté a Monsieur le Ministre de France a Buenos Aires, 1898. Anexo 5 (a). 
47. Los Andes, 25 de diciembre de 1898 y 18 de diciembre de 1900 .
48. AMREC, Fondo Argentina, Vol. 16o. Memorial presenté a Monsieur le Ministre de France a Buenos Aires, 1898 , fs. 15 .

49. AMREC, Fondo Argentina, Vol 16o. Sucesión Montesinos. Carta de Manuel Ugarte a David de Tezanos Pinto embajada de Chile en Argentina, s/d, s/n.
Entre ellos el gobernador Jacinto Álvarez, el ministro de gobierno Francisco J. Moyano y los funcionarios Severo G. del Castillo, Tiburcio Peña y Lillo, Marcos R. Flores, Juan A. Arnulphi, Salvador B. Reta, Pastor Reta, Pedro A. Guevara, Tiburcio Benegas, Julián Barraquero, Juan A. Serú, Emilio Civit, Rufino Ortega e Isaac Chavarría. Los diputados Carlos Ponce, Melitón Arroyo, Rosendo de la Torre, Daniel Calvo, Francisco Álvarez, Manuel A. Ceretti, Emiliano Guiñazú, Pedro Benegas, Cesar Villanueva, Pedro R. Godoy, Jorge Villanueva, Ramón Galigniana y Genaro Segura Walrond. Y los senadores Ramón Moran, Manuel Bermejo, Laureano Galigniana, Francisco Civit, Manuel Villanueva y Atiliano Araujo.

Coincidentemente con estos listados, posteriormente publicó en los diarios los nombres de varios de los usurpadores demandados, entre los que se incluían varias poderosas personalidades de la escena local ya nombradas, tales como los ex gobernadores Rufino Ortega y Tiburcio Benegas, otros ex gobernadores como Carlos González, o terratenientes del norte de Mendoza como Víctor Albino. ${ }^{47}$

\section{El arreglo}

Además de las personas señaladas, en el listado enviado a las embajadas chilena y francesa estaban tres instituciones bancarias involucradas con las tierras de la Merced Real: el Banco Hipotecario Nacional, el Banco de la Provincia Mendoza y el Banco Nacional de Liquidación, estos detentaban fracciones de tierra por haberlas recibido en garantía de grandes sumas de dinero prestadas y nunca recuperadas. Este procedimiento, uno de los principales negocios de la elite política y terrateniente local, fue utilizado por un sector significativo de ella para hacerse de capital en forma fraudulenta, y parece haber sido uno de los principales objetivos de los apropiadores en el caso de las tierras yermas sin regadío que conformaban la mayor parte del territorio de la merced. En connivencia con funcionarios de los bancos, se tomaban préstamos a cambio de grandes extensiones de tierra que, a pesar de su gran tamaño, tenían muy poco valor comercial pero los bancos las calificaban por mucho más valor en función de su tamaño. Precisamente, una de las principales razones del recrudecimiento de las presiones en contra de Watteau fue que debido a la paralización completa de las operaciones de compra-venta y obtención de crédito en las tierras bajo litigio, el Banco Hipotecario había denegado el otorgamiento de créditos solicitados por ocupantes de las tierras de la merced. ${ }^{48}$ El Banco Hipotecario Nacional y el Nacional de Liquidación habían acordado varios millones de pesos en hipotecas a ocupantes de la merced cuyos títulos eran falsos. Los títulos que habían sido dados por válidos procedían de herederos de Isabel Montesinos, pero apócrifos según la declaratoria de herederos de la misma. ${ }^{49}$

Un memorandum de la embajada de Chile en Buenos Aires muestra que existieron negociaciones oficiosas de la sede diplomática para lograr un arreglo para los demandantes, sugiriendo la compra por parte del Gobierno Argentino de la sucesión Montesinos. Aunque no está su firma, todo parece indicar que atrás de la propuesta se encuentra la dirección estratégica de Watteau.

El principal argumento de la propuesta negociadora es el perjuicio que le ocasiona al estado nacional las cuantiosas garantías dadas a sus bancos sobre títulos litigiosos, por deudores que no eran verdaderos dueños. La solución ofrecida sería adquirir las tierras por el Banco Nacional de Liquidación a un 
precio barato para sanear las carteras de los bancos. ${ }^{50}$ "Si compra el título, ni habrá juicios, mi reclamación diplomática, ni pérdida de un centavo para los bancos ni para el gobierno". ${ }^{51}$

El reclamo diplomático por falta de justicia a los herederos de la sucesión Montesinos fue patrocinado oficialmente por las embajadas francesa, chilena y suiza. ${ }^{52}$ Por un decreto, el gobierno argentino rechazó la demanda, en los mismos términos en que lo había hecho con al reclamo de la embajada francesa, basado en los argumentos del entonces ministro de Relaciones Exteriores (RREE) Luis María Drago, ratificada luego por el Procurador General de Justicia de la Nación y por el nuevo Ministro de RREE Montes de Oca. ${ }^{53}$

Las demandas de Watteau nunca fueron resueltas. Hacia 1904 se pierde el rastro del abogado, aunque otros continuaron infructuosamente gestionando ante el gobierno argentino una revisión del decreto de rechazo de la demanda de justicia. Gran parte de las tierras de Lavalle al norte de Mendoza, donde se encuentran las lagunas de Guanacache, pasaron a constituir tierras fiscales. Los títulos de propiedad existentes registran irregularidades al punto de que las superficies declaradas según títulos son el doble de la total del departamento. En Lavalle, como en el resto de los departamentos del norte, el legado de la merced Sayanca continuó a lo largo de todo el siglo XX, tal como denunciada el informe de Draghi Lucero a través de la venta de "derechos y acciones" de tierras o el reclamo de compensaciones a los ocupantes (Cornejo Lencina, 1961, 65). Sin embargo, existieron otros legados más importantes de la merced para los laguneros de Guanacache. Por un lado, por los propios vacíos legales generados en torno a su reivindicación y la dificultad de los especuladores para mantener una fuerza extorsiva sobre multitud de establecimientos precarios en su árido entorno, los laguneros pudieron mantener la ocupación de la mayoría del territorio hasta la actualidad. Por el otro, la merced se constituyó en un poderoso fetiche étnico-territorial a la vez que el cacique Sayanca fue un símbolo de la larga lucha por la construcción de soberanía.

\section{Confluencias estratégicas: la alianza aborigen}

En varias de sus amenazantes solicitadas publicadas en el diario Los Andes, Watteau había manifestado que su intención no era perseguir a todos los pobladores de las tierras sino a los grandes terratenientes, especuladores o propietarios ausentistas: "Que los ocupantes verdaderos que labran las tierras estén tranquilos. Con ellos me entenderé, como lo he hecho hasta hoy con muchos", afirmaba Watteau en un artículo. ${ }^{54} \mathrm{El}$ apoderado de la merced dotaba así de un supuesto carácter justiciero a sus demandas. ¿Pero quiénes eran estos "ocupantes verdaderos" que Watteau oponía a los especuladores de la oligarquía provincial, los "dotores"?

En su memorial a la embajada francesa, Watteau manifestaba que -contrariamente a las acusaciones de extranjería de sus intereses- presentaba propuestas generosas para con "los resultados del trabajo y del esfuerzo de tantas generaciones de aborígenes de un área tan vasta de la provincia". ${ }^{55} \mathrm{Al}$ leer esta parte del documento me sonó extemporánea la escueta alusión a los ocupantes de la merced como aborígenes. Sin embargo más adelante, en un anexo del memorial presentado a la embajada, me topé con un sorprendente cuadro de "Cuidadores en nombre y por cuenta de Don Julio Watteau" ${ }^{56}$ de la Merced Real, principalmente en Guanacache, que Watteau colocaba como evidencia de su posesión efectiva de la mayor parte de las tierras. Se trataba de
50. AMREC, Fondo Argentina, Vol 16o. Sucesión Montesinos. Memorandum, s/d.

51. AMREC, Fondo Argentina, Vol 16o. Sucesión Montesinos. Memorandum, s/d.

52. AMREC, Fondo Argentina, Vol 16o. Sucesión Montesinos. Carta de Manuel Ugarte a David de Tezanos Pinto s/d, s/f., pag. 1. El ciudadano Suizo Welschi, fue por quien reclamó la embajada suiza.

53. AMREC, Fondo Argentina, Vol 16o. Sucesión Montesinos. Carta de Manuel Ugarte a David Tezanos Pinto, pág. 2.

54. Los Andes, 25 de diciembre de 1898, p. 4. "Testamentaría Montesinos. Algunos de los reivindicados no son los pobres como se ha propalado".

55. AMREC, Fondo Argentina, Vol 16o. Sucesión Montesinos. Memorial presenté a Monsieur le Ministre de France a Buenos Aires, 1898, f. 16 (las cursivas son nuestras).

56. "Cuidadores en nombre y por cuenta de Don Julio Watteau de las siguientes extensiones de tierra". AMREC Fondo Argentina, Vol 160: Sucesión Montesinos. Memorial presenté a Monsieur le ministre de France a Buenos Aires, en diciembre de 1898 . 
57. Expediente sobre derechos de posesión de los campos del Rosario, 1900. AHM, Carpeta 578, doc. 3.

58. En 1899, un parte del subdelegado de Lavalle al ministro de gobierno informaba que unos tales Méndez y Quiroga aducían representar a Watteau y cobraban derechos de pesca en las Lagunas del Rosario -pese a que las tierras eran del fisco. AHM, Carpeta 577, Doc. 147, Subdelegacía de Lavalle, septiembre de 1899. José M. Funes al Mtro. de Gobierno comunica el envío del Comisario de las Lagunas del Rosario para solucionar abuso sobre pescadores.

59. Los Andes, 25 de diciembre de 1898 , p. 4. "Testamentaría Montesinos. Algunos de los reivindicados no son los pobres como se ha propalado".

6o. Domingo Villegas con Maximino Segura y Victor Albino denuncian un terreno en Villa del Rosario, Mendoza, 1 de enero de 1865. AHM, Carpeta 12O, Doc. 19. veintisiete personas, dos como poseedores individuales -Estanislao Silva y José González, con catorce leguas cuadradas- y veinticinco que compartían 100 leguas cuadradas, el equivalente a 270.000 has. Estas correspondían a los remanentes de las tierras indivisas o "campos" de la antigua reducción de Lagunas del Rosario, que hasta el momento restaban sin enajenar: José María y Florencio Ferreira; Juan Manuel y Pedro Molina; José, Juan de la Cruz, Florencio, Camilo, Rosendo y Vicente González; Román, Santiago, Daniel, Pantaleón, José María y Patricio Videla; Adolfo y Estanislao Silva; Rafael y Carmen Morales; Bernardo Salazar, Rosas Nievas, Asunción F. De Videla y Julián Quiroga. En 1900 Rosendo González, siendo comisario del departamento del Rosario reclamó una porción similar de terreno. ${ }^{57}$

Estos cuidadores eran exclusivamente habitantes de las Lagunas y las tierras a su cargo correspondían al territorio ocupado -e históricamente reclamado- por ellos. No había cuidadores designados en otras partes de la extensísima superficie reivindicada por Watteau. Este documento permite vislumbrar una serie de características estratégicas en las disputas por las tierras de Guanacache y, particularmente, en la continuidad histórica de las luchas de los laguneros.

Es muy difícil conocer el grado de adhesión de los laguneros a la gesta inmobiliaria del francés. Pero creo probable que se hayan asociado a sus demandas como parte de una estrategia histórica de alianzas y maniobras judiciales destinadas a resistir la expropiación de sus tierras. Por parte de Watteau, era una estrategia que aprovechaba las antiguas demandas e inclusive argumentos históricos y jurídicos de los laguneros -que incluían ya desde antaño el uso del testamento y la Merced Real de los caciques Sayanca. Teniendo en cuenta el carácter violento de las disputas por la ocupación de tierras de la merced denunciadas tanto por el mismo Watteau como por sus enemigos, no habría desdeñado la tradición de resistencia territorial de los laguneros. Efectivamente la ocupación de hecho de la tierra, pese a los innumerables actos de violencia sufridos desde el remoto pasado colonial, fue uno de los principales factores que permitió a los laguneros mantenerse en el área. Watteau bien puede haber pretendido asociarse con dicho poder territorial para oponerse a sectores tradicionalmente antagónicos a los laguneros -aunque estos no quedaran exentos de presiones del propio Watteau o sus personeros, como ocurrió con los derechos de pesca en las Lagunas. ${ }^{58}$

La propuesta del francés, por otro lado, puede haber seducido a los laguneros por su renovado impulso en el sistema judicial a los siempre cuestionados instrumentos jurídicos en los que, en gran parte, se basó desde el siglo XIX la defensa de su territorio. Pero también por la alianza con un actor visto como poderoso y potencialmente capaz de apoyarlos contra una elite provincial y departamental, bastante más monolítica que la del período 1820-1880 en la que los laguneros habían encontrado apoyos importantes. Watteau se acopló en efecto a las divisiones y conflictos políticos históricos entre los laguneros y los "dotores", especialmente los terratenientes del sur del departamento de Lavalle, quienes habían pasado a dominar la política departamental desde mediados de la década de 1860. En efecto, en publicaciones en el diario Los Andes Watteau había agregado a la lista de denunciados por apropiación fraudulenta de tierras de la merced a varios conocidos terratenientes del área, históricos antagonistas de los laguneros como: Juvenal Gómez, Víctor Albino, Cruz Albino, Victoriano Pastrán, Pedro Sevilla, Máximo Brizuela, Cipriano Ibáñez. ${ }^{59}$ Víctor Albino, en particular, había seguido un largo pleito contra los Laguneros en la década de 1860, el cual había sido frenado en parte gracias al testamento del cacique Sayanca esgrimido por los apoderados de los Laguneros. ${ }^{60}$ 
Pero más allá de estas conjeturas ¿Qué grado de veracidad podía tener la lista de cuidadores aborígenes realizada por Watteau, teniendo en cuenta la distancia geográfica y social entre Guanacache y el embajador francés en la Argentina?

Hay varios detalles que indican que la lista no sólo es real sino que es consistente con las tradiciones históricas de lucha territorial de los laguneros, a la vez que permite comprender mejor las continuidades la misma y su articulación con la política regional entre los siglos XIX y XX. Primero, la mención de una porción de 100 leguas cuadradas de tierra en común de los laguneros coincide aproximadamente con el territorio sin enajenar que hasta ese entonces aún detentaban. ${ }^{61}$ Segundo, los nombres inscriptos en el listado de Watteau también coinciden, en efecto, con los de pobladores que habitaban el área para la época: pescadores, puesteros y pequeños y medianos estancieros, muchos de los cuales aparecen mencionados en diversos documentos o en memorias orales de la actualidad. Significativamente, muchos de ellos eran los mismos referentes o líderes que habían demandado con anterioridad las tierras de comunidad, algunos de los cuales son mencionados en memorias recientes. La mitad había firmado en 1879 el petitorio por las tierras que incluía el pleito del Protector Juan Escalante, el Decreto de 1838 y el testamento del cacique Sayanca. ${ }^{62}$ Algunos están signados entre los ancestros huarpes o "últimos caciques" que defendieron la tierra de principios del siglo XX, que Sixto Jofré listó en la década de $1990 .{ }^{63}$ Muchos de los nuevos nombres poseen los mismos apellidos y son generalmente descendientes directos de aquellos.

José María Ferreira, por ejemplo, firmó el petitorio de 1879 en el reclamo por la invasión de sus tierras por parte de milicias y terratenientes sanjuaninos. ${ }^{64}$ Luego, junto con su hijo Florencio Ferreira, aparece en la lista de cuidadores de la merced de 1898. Florencio figura a su vez como ancestro huarpe en la lista de Sixto y era recordado en 1979 como "huarpe puro" que, según sus descendientes, había sido ladero de la heroína huarpe, bandida y montonera Martina Chapanay, "cuando viajaban las carretas de cuatro ruedas para quitarles lo que llevaban." ${ }^{65}$

La biografía de Florencio es un ejemplo del recorrido histórico de la pequeña elite lagunera de principios del siglo $\mathrm{XX}$, asociada -en gran medida- a las insurrecciones montoneras tardías lideradas por Guayama y ligada a las tradiciones históricas de lucha por las tierras indígenas. Florencio proviene de una historia de persecución política sobre los laguneros, que hacia fines de la década de 1870 junto con familiares y partidarios de Santos Guayama escaparon luego de su derrota a las Lagunas -muchos de los cuales se transformaron con el tiempo en propietarios de envergadura y líderes políticos locales. A su vez, estos mismos personajes aparecen una y otra vez ligados a los reclamos de tierras indígenas y eventualmente son adscriptos como indígenas.

En el censo de 1869 Florencio fue anotado como mendocino, de 23 años y peón. ${ }^{66}$ En 1872 acompañó a Santos Guayama en una serie de asaltos y asesinatos que precedieron a la toma del pueblo de Caucete, con el propósito fallido de avanzar en una revolución sobre la ciudad de San Juan. En las vísperas del ataque había estado en las Lagunas con otros "peones laguneros" que trabajaban en fincas de Caucete preparando la invasión, ${ }^{67}$ o eludiendo las persecuciones de la policía sanjuanina. ${ }^{68}$ En 1881 Florencio se casó en la capilla del Rosario de las Lagunas y fue anotado como de 33 años de edad "color trigueño y ejercicio pescador." 69
61. Expediente sobre derechos de posesión de los campos del Rosario, 1900. AHM, Carpeta 578, doc. 3.

62. Serían entre doce y catorce, ya que existen dos nombres dudosos: Vicente González, podría ser quien en 1879 aparece como Juan Vicente González, y Juan Molina, quien en el mismo documento está inscripto como Juan Victoriano Molina.

63. En la década de 1990 , en base a su conocimiento personal Sixto elaboró este listado para obtener la personería jurídica de la comunidad huarpe de Lagunas del Rosario. Según afirmaba, contra la idea actual de que los huarpes no tenían o no querían títulos de propiedad privada, los laguneros de principios del siglo XX habían pugnado por conseguirlos como una forma de preservar las tierras.

64. Defensa realizada por el Defensor de pobres y ausentes a los indios Laguneros, Mendoza, 10 de mayo de 1879. AHM, Carpeta 575 bis, doc. 17 , fs. 1-3.

65. Diario de Cuyo, 12 de febrero de 2006. "Homenaje: Onofre Quiroga. El ultimo Huarpe." Por A. Beorchia Nigris.

66. República Argentina (1872). Primer Censo de 1869. Mendoza, Rosario, p. 56.

67. El procurador fiscal contra Santos Díaz (ausente) por salteo en cuadrillas, San Juan, 1878. Archivo de los Tribunales de la Provincia de San Juan. Caja 1, Siglo XIX, Penal. fs. 92, 100.

68. Archivo de los Tribunales de la Provincia de San Juan. Caja 1, Siglo XIX, Penal. El procurador fiscal..., fs 71. Lo mismo es testificado por Bautista Videla en fs. 67-68 y 70.

69. Libro de Matrimonios Lavalle, Mendoza. Parroquia Nuestra Señora del Rosario 1826-1947, Vol. I, f. 8 o. 
70. República Argentina (1898). Segundo Censo de 1895. Tomo 47. Mendoza, Departamento de Lavalle, Rosario, pág. 37.

71. Debenedetti y Pozzi (1925). Diario de la XXIa Expedición a las Lagunas de Huanacache...

72. Lo mismo comentaba su nieto, Onofre Quiroga. Beorchia Nigris (2006). "Homenaje: Onofre Quiroga. El ultimo Huarpe" en Diario de Cuyo, 12 de febrero de 2006.

73. El comisario Rosendo González comunica el paso de Fuerzas Armadas de San Juan queriendo desalojar la costa de las Lagunas. Lagunas del Rosario, 24 de mayo de 1879. AHM, Carpeta 575 bis, doc. 17, y Carpeta 575 bis, doc. 18.

74. Expediente sobre derechos de posesión de los campos del Rosario, 1900. AHM, Carpeta 578, doc. 3.

75. Pozzi (1925). Diario de la XXI Expedición a las Lagunas de Huanacache..., Cuaderno 2.

76. Archivo de Juan Carlos Rusconi. Carlos Rusconi al Gobernador de la Provincia. Mendoza, 2 de Septiembre de 1941, en Rusconi (1941).

77. Correspondiente al distrito de San José, entre Lagunas del Rosario y Asunción.
En el censo nacional de 1895 aparecía como poseedor de propiedad raíz, de 45 años, casado, mendocino, agricultor y analfabeto. ${ }^{70}$ En el diario de la expedición de 1925 del Museo Etnográfico de la Universidad de Buenos Aires a las lagunas de Guanacache, Ferreira fue mencionado por el arqueólogo Salvador Debenedetti como "descendiente según se dice del cacique Sayanca". ${ }^{71}$ Para la época, y como recordaba Sixto Jofré, Florencio era un vecino importante y ocupaba un cargo de gran prestigio local, el de síndico de la capilla del Rosario de las Lagunas. ${ }^{72}$

Rosendo González, que aparece también en la lista de Watteau, era comisario de policía de las Lagunas y había sido uno de los puesteros de la orilla de la Laguna del Rosario, perseguido por el terrateniente sanjuanino José María Torres luego del asesinato de Santos Guayama. Firmó el petitorio de 1879 que los laguneros elevaron entonces para reclamar por sus tierras y vidas al gobierno de Mendoza, en el que adjuntaban el testamento del cacique Sayanca y el juicio llevado a cabo por el protector de indios de Mendoza en la década de $1830 .{ }^{73}$ En 1900, todavía como comisario local, solicitó agónicamente al mismo gobierno el reconocimiento de la propiedad común de la porción remanente de las tierras de la antigua Reducción. ${ }^{74}$ Su descendiente -y de Juan Vicente González, quien también aparece en los listados de Watteau y de Sixto JofréJuan Esteban González, como hemos mencionado al principio de este artículo, afirmó en 1925 al continuador de la expedición de Debenedetti, José Pozzi, que tenía una copia de la escritura de Sayanca de $1713 .{ }^{75}$ Fue fotografiado por Rusconi en la década de 1930, durante su movilización a Mendoza en 1936 con un contingente de laguneros, y a solicitud de éste obtendría su jubilación como "indio" en $1941 .^{76}$

Carmen y Rafael Morales firmaron el petitorio de 1879 y se encuentran señalados como cuidadores de Watteau. En la lista de Sixto no están pero sí otros Morales descendientes directos de los anteriores, como Salvador Morales propietario de tierras y una finca y mencionado como baqueano de Métraux, Debenedetti y Rusconi entre las décadas de 1910 a 1930. En general, en los tres documentos aparecen los apellidos más extendidos en el área de Lagunas del Rosario hasta la actualidad. González, Molina, Videla, Nievas, Quiroga y Salazar.

Según se desprende de los análisis precedentes existió una continuidad en la participación de determinadas personas y sus descendientes directos en los petitorios y listas relacionadas con demandas por las tierras. Esta continuidad es consistente con un relevo generacional en los liderazgos para el sostenimiento de las luchas por las tierras, al menos entre principios del siglo XIX y la primera mitad del siglo XX.

Estos relevos generacionales se han producido a veces tras varias décadas, no siendo raro el caso de que sólo dos o tres de los mismos unan un siglo y medio de historia. Esto ocurrió con los Villegas: Domingo Villegas ejerció un largo liderazgo y ocupó cargos públicos, movilizando las demandas de tierras desde 1819 hasta la década de 1860. Su hijo Juan Manuel Villegas, que da el nombre a una Comunidad Huarpe de la actualidad, ${ }^{77}$ fue un importante estanciero a nivel local que desempeñó cargos comunitarios como el de Síndico de la capilla del Rosario, participó de la movilización a Mendoza en 1936, cuando fue fotografiado por Rusconi, y al año siguiente fue pintado por Fidel Roig Matons en la serie "vestigios huarpes". En la actualidad, el anciano nieto de Juan Manuel, el "Tano" Villegas, recuerda claramente que Domingo era Juez 
de Paz, jefe político y económico del paraje de San José. Y sobre todo, muy amigo del famoso caudillo lagunero Santos Guayama.

\section{Conclusión}

La historia que hemos analizado en este artículo evidencia la sorprendente extensión temporal del proceso colonial y la resistencia al mismo en el contexto de la "Argentina blanca", a través de culturas políticas, una historia judicial y memorias indígenas en una época y área en las cuales se consideraba que sólo quedaban vagos remantes folclóricos de los antiguos huarpes "transmutados" en criollos.

Contra la imagen de la "institucionalidad mendocina" que tiene a la elite de fines del siglo XIX como su principal referente, la oligarquía local se caracterizó por el nepotismo, la corrupción y la violencia en la construcción de su control político y la colonización republicana de su territorio y recursos. Las apropiaciones ilegales y negociados con las tierras, que aumentaron drásticamente en el norte de la provincia luego del asesinato del caudillo Santos Guayama en 1879 y a partir del mismo año en el sur con la Campaña del Desierto, fueron una de las principales vías de enriquecimiento de esa elite. Como explicara el dirigente socialista Benito Marianetti con respecto a la propiedad de la tierra, tal vez exagerando algo, "de un plumazo se otorgaban concesiones de miles de hectáreas" según la influencia política del interesado (Marianetti, 1948: 88).

La saga periodística y diplomática de Watteau desnuda estos hechos y, en perspectiva, evidencia el grado de ocultamiento histórico de los mismos. Ningún historiador mendocino abordó jamás el caso, aunque esporádicamente mencionaron a la Merced Real del cacique Sayanca como una curiosidad. Las pericias realizadas por la Universidad Nacional de Cuyo sobre la merced a mediados del siglo XX, bajo la dirección del historiador y folclorista Juan Draghi Lucero, evitaron analizar la compleja trama de litigios protagonizados por el francés, tildándolas de maquinaciones fantasiosas y sin sustento pero, al mismo tiempo, ocultaron las demandas desarrolladas por los laguneros (Escolar, 2019). Esto resulta notable ya que Draghi Lucero escribió abundantemente sobre los laguneros de Guanacache, ambientando en las lagunas y el desierto circundante sus principales obras, y es muy difícil que no hubiera conocido los reclamos concretos -y sostenidos en el tiempo- sobre sus tierras (Draghi Lucero, 1940, 1978). En efecto, como hemos mostrado, viajeros ocasionales contemporáneos de los viajes de Draghi Lucero a Guanacache en la década de 1930 fueron sorprendidos por pobladores locales que mostraban copias del testamento y la Merced Real de los caciques Sayanca, entre otros documentos, invocando en base a los mismos sus derechos territoriales en tanto indios. Es posible inclusive que estos discursos y prácticas hayan sido potenciados por las maniobras de Watteau y su designación de laguneros como "cuidadores" de la merced. Debemos cuidarnos, sin embargo, de concluir que fue Watteau quien creó dichas prácticas y discursos. La utilización de ese documento y el testamento de los Sayanca data, como hemos visto, por lo menos de la primera mitad del siglo XIX, y la realización de diversas estrategias legales, políticas e incluso militares para sostener la posesión y propiedad de las tierras de Guanacache puede rastrearse hasta principios del siglo XVIII. Esta historia política y judicial atravesó diversas generaciones de laguneros durante las guerras civiles de ese siglo hasta la década de 1930 y con menos intensidad a lo largo del siglo XX, hasta renacer con fuerza a fines de ese siglo hasta la actualidad. 
Buena parte de la historiografía suele mostrarse reactiva a analizar sujetos que no aparecen claramente delimitados en relación con el resto de la sociedad y la comunidad política. Se siente más cómoda con la engañosa nitidez que deparan los indígenas fronterizos del poder colonial o estatal nacional, supuestamente categorizables en unidades culturales, sociales, políticas y hasta morales distintivas, según su carácter resistente al proceso colonial. No es el caso de los sujetos que nos ocupan, aquellos que Joao Pacheco de Oliveira describe como "indios misturados" (Pacheco de Oliveira, 1998), o que yo he denominado para Argentina -con otros matices- "indios de intramuros" (Escolar, 2007). Es decir, grupos que han mantenido hasta el presente una relación ambigua y, en algunos casos, notablemente persistente y significativa con su indigenidad al interior de los espacios geográficos y sociales de colonización temprana considerados en general no-indígenas.

En realidad, si bien no podemos atribuir a actores externos la producción de las estrategias de los laguneros tampoco podemos separarlas taxativamente de luchas políticas más generales a nivel regional y nacional, ni de las maniobras de sectores de las elites para la apropiación de las tierras y el agua. Las disputas históricas por las tierras de Guanacache incluyeron una, a veces, inextricable articulación con sus enemigos sociales en un juego de larga duración de alianzas y conflictos. Uno de los aspectos más notables del caso es que sectores en conflicto, indígenas y no indígenas, construyeron legitimidad de la propiedad y soberanía apelando en forma selectiva y alternada, pero recurrente al menos hasta principios del siglo XX, a la aboriginalidad como fuente de derechos eminentes. La Merced Real del cacique Sayanca, no obstante la alegación de su falsedad fue considerada válida en distintos momentos por estos actores antagónicos, reforzando a la larga, en definitiva, una noción clave: la existencia de derechos indígenas precedentes a la provincia y a la nación, el carácter legítimo de la propiedad y el territorio indígenas como fuente primaria de soberanía y propiedad. 


\section{Bibliografía y fuentes}

\section{Repositorios}

»Archivo Eclesiástico de Mendoza

»Archivo Fotográfico y Documental del Museo “Juan Bautista Ambrosetti” Archivo del Ministerio de Relaciones Exteriores de Chile

»Archivo Histórico de Mendoza (AHM)

» Archivo Histórico de San Juan

» Archivo de Juan Carlos Rusconi

»Archivo de Juan Nievas

»Archivo de Sixto Jofré

\section{Periódicos}

》Diario de Cuyo

»La Prensa

»Los Andes 


\section{Q Referencias bibliográficas}

» Bragoni, B. (1999). Los Hijos de la Revolución. Madrid, Taurus.

» Bragoni, B. y R. Jorba (1993-1998). Acerca de una nueva economía regional. Xama 6-11: 223-236.

»Canals Frau, S. (1946). Etnología de los huarpes. Una síntesis. Anales del Instituto de Etnología Americana 7: 9-149.

»Castellanos, A. (1926). Un viaje por las lagunas de Huanacache y el Desaguadero. Sociedad Luz Serie II, 3 (47).

»Cornejo Lencina, A. (1961). La Falsa Merced Real de 1713, a favor del Cacique Sayanca. Mendoza, Mundo Cuyano.

» Cueto, A. O. (1988). Dos intentos enfitéuticos en la legislación sobre tierra pública en Mendoza, en el siglo XIX. Revista de Estudios Regionales 1: 73-100.

» Cueto, A. O. (1989). La legislación hispánica sobre tierras y su vigencia en la Mendoza colonial (siglos XVI-XIX). Revista de Estudios Regionales 3: 65-108.

»Draghi Lucero, J. (1940). Las Mil y una Noches Argentinas. Buenos Aires, Kraft.

»Draghi Lucero, J. (1978). La Cabra de Plata. Buenos Aires, Castaneda.

»Escolar, D. (2007). Los Dones étnicos de la Nación. Identidades huarpes y modos de producción de soberanía en Argentina. Buenos Aires, Prometeo.

"Escolar, D. (2013). Huarpes Archives in the Argentine Desert: Indigenous Claims and State Construction in Nineteenth-Century Mendoza. Hispanic American Historical Review 93 (3): 451-483.

»Escolar, D. (2015). Jueces indígenas, caciques criollos: autonomía y estatalidad en Guanacache, Mendoza (siglo XIX). Tiempo Histórico 9: 37-72.

»Escolar, D. (2018). La república perdida de Santos Guayama. Demandas indígenas e insurrecciones montoneras en Cuyo, Argentina, siglo XIX. Estudios Atacameños, Arqueología y Antropología Surandinas 57: 140-164.

»Escolar, D. (2019). La merced real del cacique Sayanca: aboriginalidad, propiedad y soberanía en Argentina. Escolar, D. y L. Rodríguez (comps.), Más allá de la extinción: Identidades indígenas en la Argentina criolla, siglos XVIII-XX: 139-164. Buenos Aires, SB Editorial

»Escolar D. y L. Rodríguez (comps.) (2019). Más allá de la extinción: Identidades indígenas en la Argentina criolla, siglos XVIII-XX. Buenos Aires, SB Editorial.

»Escolar, D. (2020). Los ‘últimos caciques’ de Cuyo. Tierras, política y memorias indígenas en la Argentina criolla (Mogna, siglos XVII-XIX). Revista del Museo de Antropología 13 (2). (En prensa).

"Espejo, J. L. (1954). La provincia de Cuyo del reino de Chile. Santiago de Chile, Imprenta Universitaria.

» Fandos, C. (2007). Estructura y transferencia de la propiedad comunal de Colalao y Tolombón (provincia de Tucumán) en la segunda mitad del siglo XIX. Mundo Agrario, 7 (14). Disponible en Internet: http://www.mundoagrario.unlp.edu.ar/article/view/ vo7n14a12. Consultada el: 8 de febrero de 2019.

»Florescano, E. (2002). El canon memorioso forjado por los Títulos Primordiales. Colonial 
Latin American Review 11 (2): 183-230.

» Gibson, Ch. (1975). “Prose Sources in the Native Historical Tradition” en Cline, H. E (ed.), Handbook of Middle American Indians 15 (4): 311-321. Austin, University of Texas Press.

»Isla, A. (2002). Los usos políticos de la identidad. Indigenismo y Estado, Buenos Aires, Editorial de las Ciencias.

» Mata Olmo, R. (1992). Aportaciones al problema de la tierra en las zonas áridad de la provincia de Mendoza. Malargüe, 1874-1988. Boletín de Estudios Geográficos XXV (88): $55-89$.

" Marianetti, B. (1948). Problemas de Cuyo. Buenos Aires, Lautaro.

» Massini Calderón, J. L. (1994). Tierra irrigación y colonización en Mendoza a principio del siglo XX (1900-1917). Revista de Estudios Regionales 11: 101-150. Mendoza, CEIDER.

» Menegus Bornemann, M. (1994). Los títulos primordiales de los pueblos de indios. Estudios. Revista de historia moderna 20: 207-230.

» Michieli, C. T. (1983). Los huarpes protohistóricos. San Juan, Universidad Nacional de San Juan, Instituto de Investigaciones Arqueológicas y Museo.

» Michieli, C. T. (200o). La disolución de la categoría jurídico-social de "indio" en el siglo XVIII: El caso de San Juan (Región de Cuyo). San Juan, Universidad Nacional de San Juan, Facultad de Filosofía Humanidades y Artes, Instituto de Investigaciones Arqueológicas y Museo.

» Morales Guiñazú, F. (1938). Primitivos habitantes de Mendoza. Mendoza, Best Hermanos.

» Morales Guiñazú, F. (1961). “Informe de la junta de estudios históricos de Mendoza” en Cornejo Lencina, A., La Falsa Merced Real de 1713 a favor del Cacique Sayanca: 32-33. Mendoza, Mundo Cuyano.

" Oliveira, J. P. (1998). Uma etnología dos “indios misturados”? Situaçâo colonial, territorializaçâo e fluxosculturais. Mana 4 (1): 47-77.

»Prieto, M. del R. (1976). El proceso de aculturación de los huarpes de Mendoza”. Anales de Arqueología y Etnología XXIX-XXXI: 237-272.

»Prieto. M. del R. (2000). Formación y consolidación de una sociedad de frontera en un área marginal del Reino de Chile: La provincia de Cuyo en el siglo XVII. Anales de Arqueología y Etnología 52-53: 17-366.

» República Argentina (1872). Primer Censo de 1869. Buenos Aires, Imprenta El Porvenir.

» República Argentina (1898). Segundo Censo de 1895. Buenos Aires, Taller tipográfico de la penitenciaría nacional.

" Richard Jorba, R. (1998). Poder, economía y espacio en Mendoza (1850-1900). Del comercio ganadero a la agroindustria vitivinícola. Mendoza, Facultad de Filosofía y Letras, Universidad Nacional de Cuyo.

» Richard Jorba, R. (2000-2001). El mercado de trabajo rural en Mendoza. Un panorama sobre su formación y funcionamiento entre la segunda mitad del siglo XIX y comienzos del XX. Coacciones, regulaciones y trabajo libre. Población y Sociedad 8/9: 211-268.

» Rodríguez, L. (2011a). “El viaje de Don Lorenzo y otros “peregrinajes”. Reclamos territoriales, identidad y memoria en la comunidad de Amaicha del Valle" en Rodríguez, L. (comp.), Resistencias, conflictos y negociaciones. El valle Calchaquí desde el período prehispánico hasta la actualidad: 123-144, Rosario, Prohistoria.

» Romero Frizzi, M. A. (2011). Conflictos agrarios, historia y peritajes paleográficos. Reflexionando desde Oaxaca. Estudios Agrarios 17 (47): 65-81. 
»Rusconi, C. (1941). “Ayuda a los últimos aborígenes de la provincia”. Mimeo.

"Sosa, J. (2015a). Amaycha la identidad persistente. Procesos de territorialización, desterritorialización y reterritorialización en una comunidad tricentenaria. Tesis de doctorado. Buenos Aires, Universidad de Buenos Aires. Disponible en Internet: http:// repositorio.filo.uba.ar/handle/filodigital/2958. Consultada el: 8 de febrero de 2019 .

"Sosa, J. (2015b). “La Cédula Real de los Amaycha”. Contextualización, análisis y transcripción de un documento controversial”. Corpus. Archivos virtuales de la alteridad americana 5 (1). Disponible en Internet: http://corpusarchivos.revues.org. Consultada el: 15 de octubre de 2018.

» Tell, S. (2012). Conflictos por tierras en los 'pueblos de indios' de Córdoba. El pueblo de San Marcos entre fines del siglo XVII y principios del siglo XIX. Andes. Antropología e Historia 23 (1): 71-103.

» Watteau, J. (s/f.). Sucesión Montesinos. s/e.

»Zuloaga, R. (1961). Crítica de autenticidad de una Merced Real de 1713. En A. Cornejo Lencina, La Falsa Merced Real de 1713, a favor del Cacique Sayanca: 25-30. Mendoza, Mundo Cuyano. 